\title{
Diverse More Than Ever
}

\author{
Nao YAMAUCHI ${ }^{\mathrm{a})}$ and Hidenori SATO ${ }^{\mathrm{b})}$
}

\begin{abstract}
The results of prior research on the impact of top management team (TMT) diversity on corporate performance have been varied and inconsistent. In this study, the operational definitions of TMT and diversity were checked in academic papers published between 2005 and 2020 on TMT diversity. The results confirmed three patterns for the operational definition of TMT: (a) extracted by title rank, (b) selected by CEO or equivalent top manager, and (c) executives announced in the company's public information/database. As for diversity, in addition to the studies that use conventional indices that express the various attributes of executives, it was confirmed that there exist many studies that consider diversity from the aspects of separation and disparity. Such "diversity" in the operational definition is considered the cause of the lack of consistency between TMT diversity and corporate performance.
\end{abstract}

Keywords: top management team, diversity, upper echelons theory

\footnotetext{
a) Graduate School of Business Sciences, Humanities and Social Sciences, University of Tsukuba, 3-29-1 Otsuka, Bunkyo-ku, Tokyo, Japan, s2140413@s.tsukuba.ac.jp

b) Faculty of Business Sciences, University of Tsukuba, 3-29-1 Otsuka, Bunkyo-ku, Tokyo, Japan, sato.hidenori.fn@u.tsukuba.ac.jp

NY and HS were involved in conception and design of the study. NY collected and assembled the data. NY drafted the manuscript. NY and HS critically commented on drafts of the manuscript. NY and HS read and approved the final manuscript.

The authors declare there are no competing interests.

A part of this article was presented at the ABAS Conference 2021 Summer (Yamauchi \& Sato, 2021).

(C) 2021 Nao Yamauchi and Hidenori Sato. This is an Open Access article distributed under the terms of the Creative Commons Attribution License CC BY 4.0 (Attribution 4.0 International) license. The CC BY 4.0 license permits unrestricted reuse, distribution, and reproduction in any medium, provided the original work is properly cited.
} 


\section{Introduction}

The top management team (TMT) is the strategic decision-making unit of a company, within which situations are interpreted and decisions are made based on the cognitive ability and characteristics of the executives involved (Hambrick \& Mason, 1984; Neely, Lovelace, Cowen, \& Hiller, 2020). This has led to a recognition of the need for research on the impact of TMT executive diversity on organizational performance (Nielsen, 2010a), and research is still ongoing. However, it has been noted that the results of studies examining the ultimate impact of TMT diversity on firm-level outcomes, such as performance, are varied and inconsistent (Neely et al., 2020; Nielsen, 2010a).

In response to this situation, this study extracted 47 empirical research papers on TMT diversity published over the last 15 years in order to examine the operational definitions of TMT and diversity. The review of these 47 papers found that the definition of TMT as a strategic decision-making unit of a company, wherein the situation is judged based on the cognition and characteristics of the executives, was consistent. However, the operational definitions used in prior empirical studies differed from study to study, and it became clear that the operational definition of TMT can be categorized into three patterns depending on how the scope of executives that make up the TMT is set.

As for diversity, in line with the definition of diversity as the distribution of personal attributes among members (Jackson, Joshi, \& Erhardt, 2003), Herfindahl-Hirschman Index (HHI) and Blau's (1977) index were used in many cases as variables to express the degree of distribution for those attributes that can be categorized. For other indicators that can be expressed by continuous and discrete variables, standard deviation and coefficient of variation were used in many cases.

In addition, the overall tendency for variable settings is that there 
are a greater number of variables related to deep-level diversity (Joshi $\&$ Roh, 2009), such as tenure and functional background, which are linked to skills and abilities, rather than superficial attributes such as gender.

In addition, some studies consider diversity from the perspective of disparity and separation, clarifying that the indicators of diversity in TMT are not limited to demographic characteristics but are becoming more diverse in both type and scale.

\section{Method}

This study was conducted on EBSCOhost using, as a reference, the methodology of Nielsen (2010a) that reviewed empirical studies published between 1984 and 2005 on the diversity of TMT and its effects, and the papers were extracted by searching for those that use seven keywords__upper echelons," "top management," "TMT," "board of directors," "corporate boards," "chief executive officer," and "CEO" - that appear in the Academy of Management Journal, Administrative Science Quarterly, Journal of Applied Psychology, Journal of International Business Studies, Journal of Management, Journal of Management Studies, Organization Science, Management International Review, Management Science and Strategic Management Journal. The period covered in this study was 2005 to 2020 or the period after 1984 and 2005 that was covered by Nielsen (2010a).

As a result of the above-mentioned search, 840 papers were extracted. The list was then narrowed down to those related to TMT and TMT diversity, heterogeneity, and team characteristics, and finally, 47 papers were selected for this review. As the study covered TMT alone, papers that dealt with the board but were not related to TMT were not considered. 


\section{Operational Definition of TMT}

Now, let us verify the actual definition of TMT used in the 47 papers. All the papers were based on the upper echelons theory (Carpenter, Geletkanycz, \& Sanders, 2004; Cho \& Hambrick, 2006; Finkelstein, Hambrick, \& Cannella, 2009; Hambrick, 1994; Hambrick \& Mason, 1984) that states that TMT is the strategic decision-making unit of a company that is responsible for interpreting situations and making decisions based on the cognitive abilities and characteristics of executives. In other words, the definition that TMT is the corporate strategic decision-making unit in which the characteristics and capabilities of the executives who make up the unit are important factors was consistent across all of the papers.

However, in the operational definition of TMT that is used in empirical studies, we found that the scope of TMT varies from study to study, depending on the extent to which executives are specifically covered. Table 1 summarizes the three patterns that were identified.

First, in Category I, TMT is extracted by title rank. This method is primarily used for listed companies for which archival data is available. Among these companies, there is a difference in whether the scope of TMT is defined as Vice President (VP) and above or upperclass vice presidents like Executive Vice President (EVP) and above or Senior Vice President (SVP) and above. Related to this difference in operational definitions, Certo, Lester, Dalton, and Dalton (2006) suggested the possibility that the inconsistent relationship between TMT diversity and corporate performance may be due to the different operational definitions of TMT across studies. Category I is a way of strictly separating the scope of TMT mechanically using the title rank of each executive. In addition, there were differences in the delimitations of VP, EVP, and SVP among the studies. It is safe to say that that as long as the way VPs, EVPs, and SVPs are involved in 


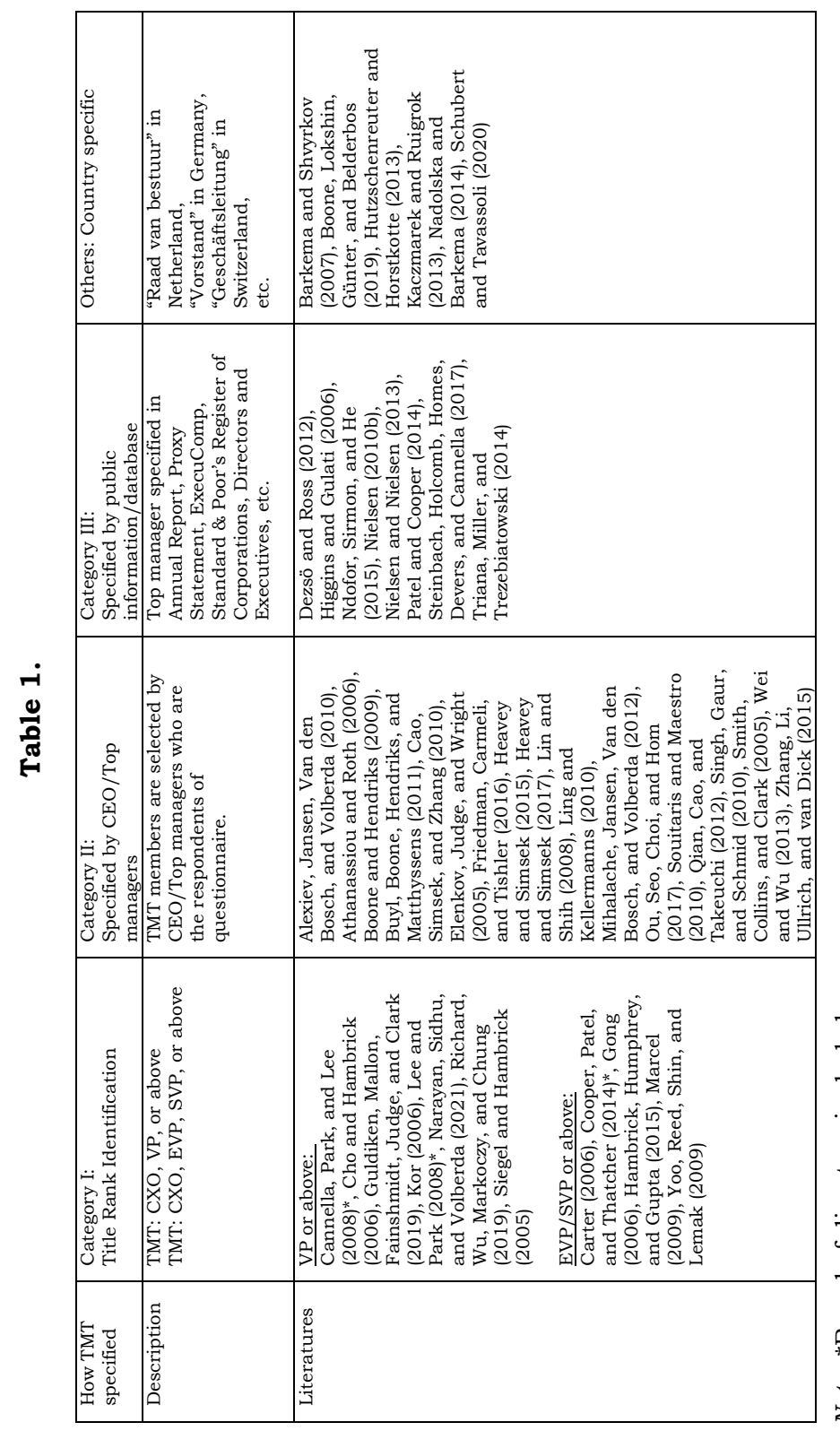

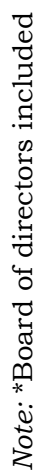


strategic decision making is different in each company, and as long as the scope of TMT is mechanically divided and its criteria are not standardized across studies, the differences in operational definitions presented by Certo et al. (2006) remain unresolved at the present time.

Next, Category II is defined as TMT in which the CEO or equivalent top manager selects executives who are involved in strategic decision making (Knight, Pearce, Smith, Olian, Sims, Smith, \& Flood, 1999; Smith, Smith, Olian, Sims, O’Bannon, \& Scully, 1994). This definition is used for companies for which archival data cannot be obtained, such as unlisted companies and small- and medium-sized companies, rather than listed companies, and for questionnaire surveys. In fact, since the CEO or equivalent top manager of each company selects the executives who are involved in strategic decision making as TMT, it can be argued that there is no difference between the conceptual definition of TMT as a strategic decision-making unit and the selected executive and the operational definition.

Finally, Category III defines TMT as executives whose names appear in the company's public information, such as annual reports, proxy statements, web sites, and databases such as ExecuComp, Standard \& Poor's Register of Corporations, and Directors and Executives. Even though the executives whose names are publicized by companies may not be very highly involved in strategic decision making at some companies, this would be a more reliable method than uniformly dividing by title rank as in Category I.

The majority of the studies that were included in this study was focused on U.S. companies. ${ }^{1}$ For non-U.S. companies, particularly in the case of German, Dutch, and Swiss companies, there are examples that are defined by country-specific terms such as "Vorstand," "Raad

1 The locations of the companies studied were the U.S. in 26 papers, Europe in 14 papers, China in 6 papers, and Taiwan in 1 paper. 
van Bestuur," and "Geschäftsleitung," respectively, which are summarized as "others" in Table 1. For example, the corporate governance structure in Germany is two-tiered with the "Vorstand," the executive board, and the "Aufsichtrat," the supervisory board, and it should not be a problem to regard "Vorstand" as TMT either in conceptual definition or in operational definition.

\section{Operational Definition of Diversity}

Table 2 summarizes the main variables ${ }^{2}$ representing diversity and their measurement methods that were found to be used in the 47 papers.

According to Jackson et al. (2003), diversity is defined as "the distribution of personal attributes among interdependent members of a work unit" (Jackson et al., p. 802).

As per the definition of diversity given by Jackson et al. (2003), the papers extracted for our study adopted the approach of observing the distribution of attributes of executives that make up the TMT as diversity. As measurement methods, the HHI (Herfindahl-Hirschman Index) or Blau's (1977) index (1 minus the HHI) was used for those that could be categorized, and for other continuous and discrete variables, standard deviation, coefficient of variation, and mean values were generally used.

As for the attributes of diversity, functional background was the most frequently used (19 papers), followed by team tenure (18 papers) and education (16 papers). For functional background and education, most papers categorized each attribute and used HHI or Blau's index to measure the degree of distribution. In some cases, educational history was measured in years, and the standard deviation and

2 Categorization was made based on measurement metrics, and the list below shows those that were confirmed to have two or more of them. 


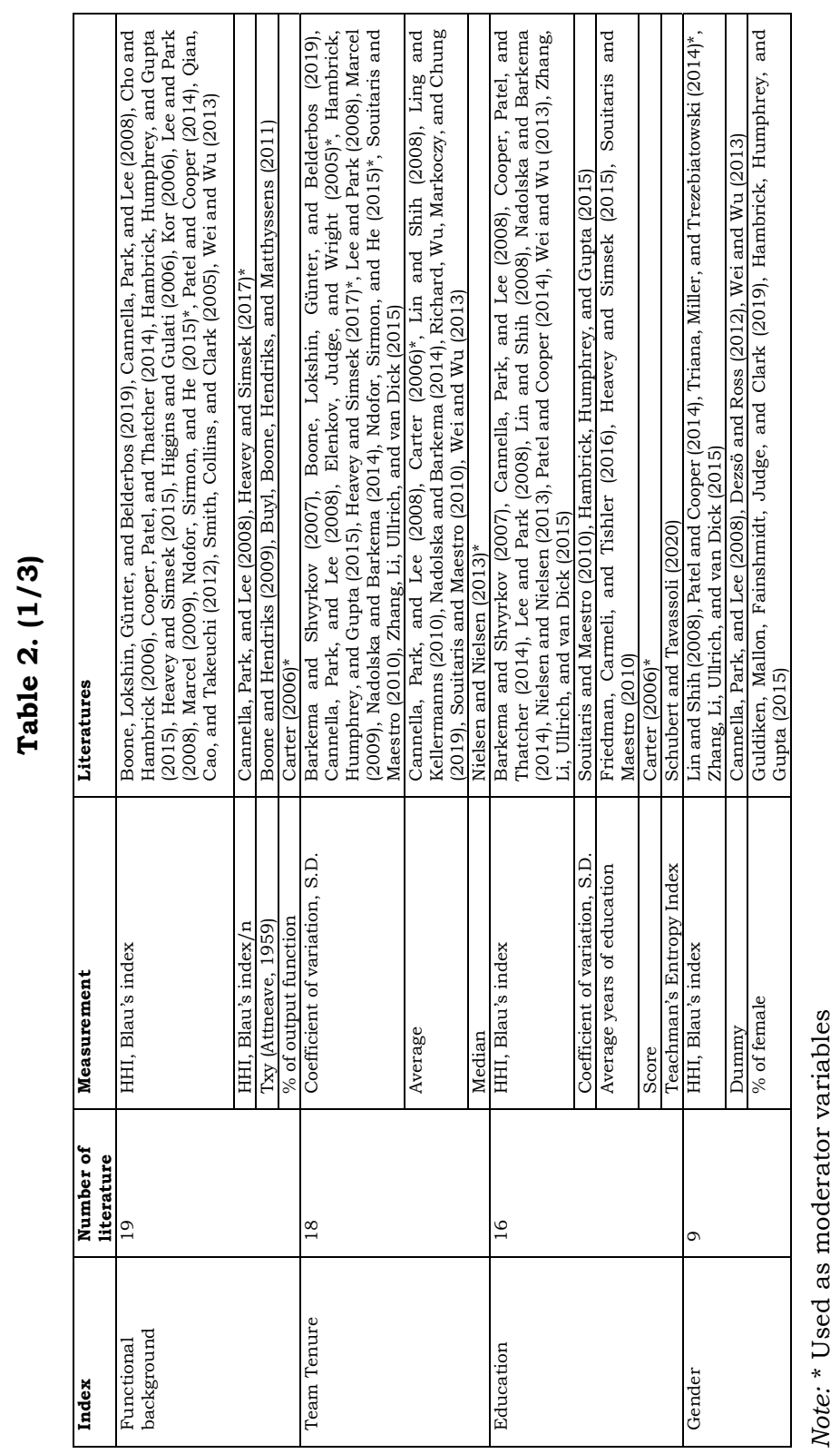




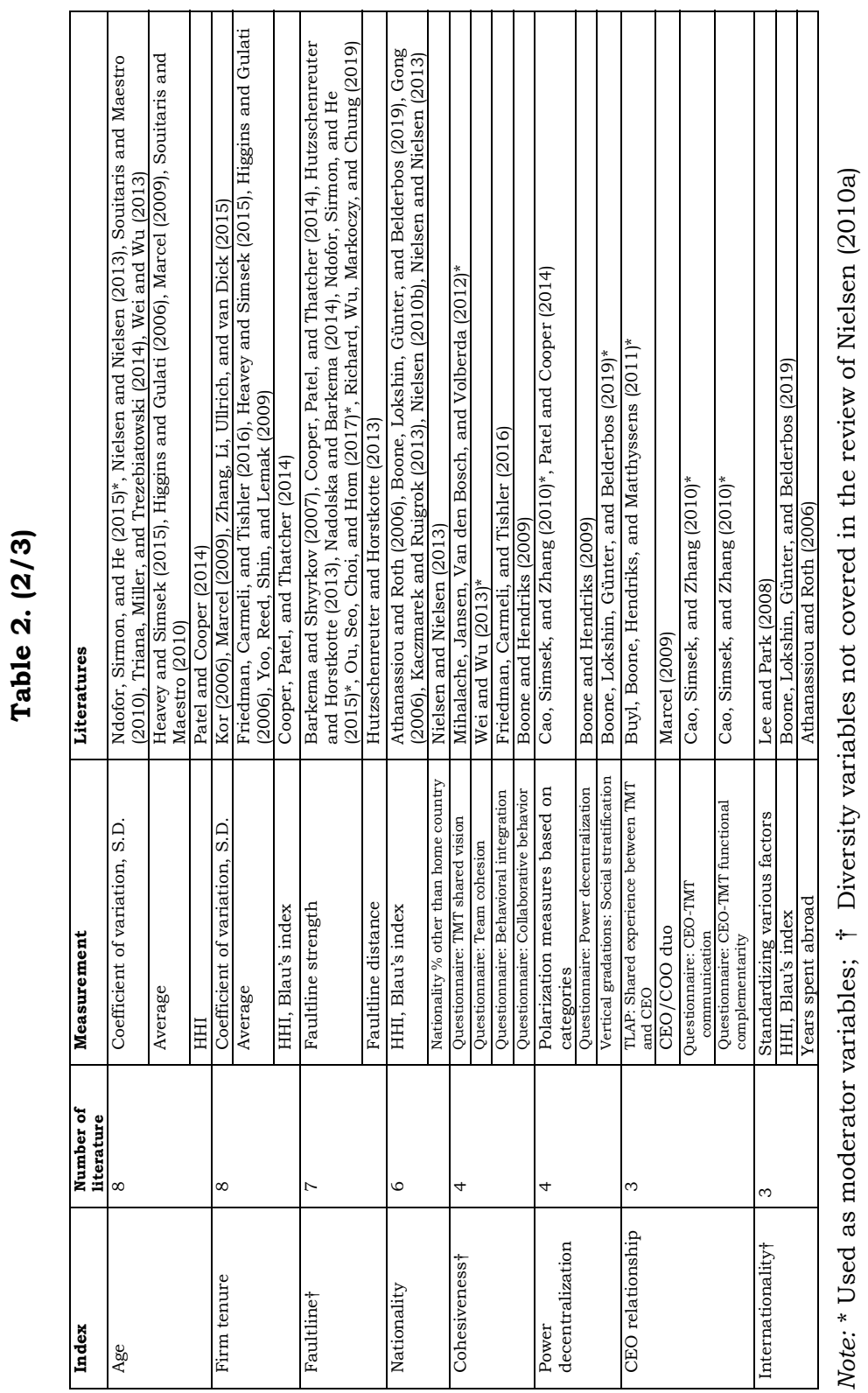




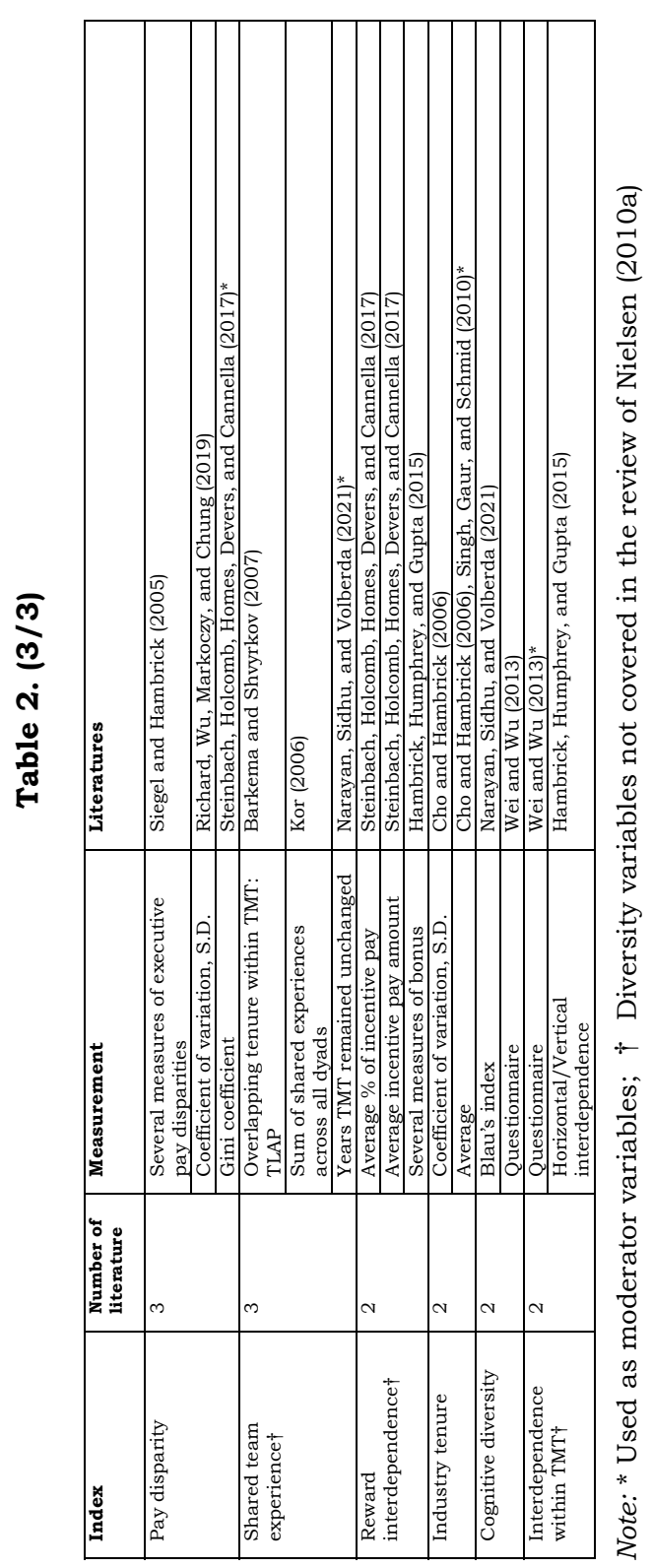


coefficient of variation were calculated and considered as the degree of distribution of educational history. As for team tenure, patterns were seen that in some cases, the distribution was verified using the standard deviation and the coefficient of variation, and in some other cases, using the mean number of years since each executive became a TMT member.

For gender, which was the next most frequently used variable (9 papers), as in the cases of other diversity variables, the pattern of using HHI or Blau's index and the pattern of calculating the percentage of a specific gender (e.g., female) were observed. Incidentally, this method of using the percentage of a particular category is also used for other diversity indicators. In the case of, for example, nationality, there were papers in which the percentage of people who come from places other than the company's home base was measured (Nielsen \& Nielsen, 2013), and it can be said that this method is used when focusing on a specific attribute.

The use of any of the diversity variables discussed so far was confirmed in 33 of the 47 papers that were reviewed in this study. These are orthodox methods of measuring diversity that look at the distribution of attributes of each executive, as defined by Jackson et al. (2003). In addition, the diversity variable tends to focus more on deep-level diversity (Joshi \& Roh, 2009), which is related to executive skills and knowledge, rather than demographic attributes such as gender.

Then, a method called faultline (Lau \& Murnighan, 1998) was also used to measure imaginary fault lines within the group by combining these individual attributes as one or more variables.

For the remaining variables, not only the demographic and labelable attributes of each executive (attribution), such as the degree to which each executive shares the same vision, the directionality of each executive, and indicators of disparity such as power decentralization and pay disparity, but also indicators of the 
executive's status were used. In addition, these indicators were frequently used not only as explanatory variables but also as moderator variables (e.g., Boone, Lokshin, Günter, \& Belderbos, 2019; Cao, Simsek, \& Zhang, 2010).

Harrison and Klein (2007) argued that there are three types of diversity within a work unit: separation, variety, and disparity. It could be argued that the main variable in prior researches on diversity has been variety. However, when the reviewed studies were compared to the types of diversity suggested by Harrison and Klein (2007), many studies attempted to measure diversity from the perspective of separation, which refers to differences in position and opinion, and disparity, which refers to disparities in valuable social assets and resources, such as salary and positions, in order to capture the status of each executive. This clarified that there is a growing focus on these indicators.

\section{Conclusion}

This study confirms the operational definitions of TMT and diversity in major studies on TMT and diversity conducted from 2005 to 2020. The results showed that the operational definitions of TMT differed in prior researches and could be categorized into three patterns.

In terms of diversity, not only demographic attributes of executives but also deep-level diversity indicators related to skills and abilities (Joshi \& Roh, 2009) were often used. These findings show diversity as the variety of attributes held by each executive, which is consistent with the definition of diversity as the degree of distribution of attributes (Jackson et al., 2003). At the same time, this study also confirmed that there are many cases in which TMT diversity is measured using the aspects of separation and disparity, as proposed by Harrison and Klein (2007). 
Diversity research has spread from the U.S. to the rest of the world, and the measurement methods used are becoming more diverse. In future research, a more careful consideration of the context of country, ${ }^{3}$ industry, and firms to be analyzed, as well as theory and measurement levels, will be required.

\section{Acknowledgments}

This work was supported by JSPS KAKENHI Grant Number JP19K13767.

\section{References}

Alexiev, A. S., Jansen, J. J. P., Van den Bosch, F. A. J., \& Volberda, H. W. (2010). Top management team advice seeking and exploratory innovation: The moderating role of TMT heterogeneity. Journal of Management Studies, 47(7), 1343-1364. doi: 10.1111/j.14676486.2010.00919.x

Athanassiou, N., \& Roth, K. (2006). International experience heterogeneity effects on top management team advice networks: A hierarchical analysis. Management International Review, 46(6), 749-769. doi: 10.1007/s11575-006-0125-3

Barkema, H. G., \& Shvyrkov, O. (2007). Does top management team diversity promote or hamper foreign expansion? Strategic Management Journal, 28(7), 663-680. doi: 10.1002/smj.604

Blau, P. M. (1977). Inequality and heterogeneity. New York, NY: Free Press. Boone, C., \& Hendriks, W. (2009). Top management team diversity and firm performance: Moderators of functional-background and locus-ofcontrol diversity. Management Science, 55(2), 165-180. doi: $10.1287 /$ mnsc. 1080.0899

3 The differences between firms in different countries have been emphasized in various fields, not only in TMT research. Examples of studies that focus on the characteristics of Japanese firms include Takahashi $(2014,2015)$ and Takahashi, Ohkawa, and Inamizu (2014). 
Boone, C., Lokshin, B., Günter, H., \& Belderbos, R. (2019). Top management team nationality diversity, corporate entrepreneurship, and innovation in multinational firms. Strategic Management Journal, 4O(2), 277-302. doi: 10.1002/smj.2976

Buyl, T., Boone, C., Hendriks, W., \& Matthyssens, P. (2011). Top management team functional diversity and firm performance: The moderating role of CEO characteristics. Journal of Management Studies, 48(1), 151-177. doi: 10.1111/j.14676486.2010.00932.x

Cannella, A. A., Park, J., \& Lee, H. (2008). Top management team functional background diversity and firm performance: Examining the roles of team member colocation and environmental uncertainty. Academy of Management Journal, 51(4), 768-784. doi: 10.5465/AMJ.2008.33665310

Cao, Q., Simsek, Z., \& Zhang, H. (2010). Modelling the joint impact of the CEO and the TMT on organizational ambidexterity. Journal of Management Studies, 47(7), 1272-1296. doi: 10.1111/j.14676486.2009.00877.x

Carpenter, M. A., Geletkanycz, M. A., \& Sanders, W. G. (2004). Upper echelons research revisited: Antecedents, elements, and consequences of top management team composition. Journal of Management, 30(6), 749-778. doi: 10.1016/j.jm.2004.06.001

Carter, S. M. (2006). The interaction of top management group, stakeholder, and situational factors on certain corporate reputation management activities. Journal of Management Studies, 43(5), 11451176. doi: 10.1111/j.1467-6486.2006.00632.x

Certo, S. T., Lester, R. H., Dalton, C. M., \& Dalton, D. R. (2006). Top management teams, strategy and financial performance: A meta-analytic examination. Journal of Management Studies, 43(4), 813-839. doi: 10.1111/j.1467-6486.2006.00612.x

Cho, T. S., \& Hambrick, D. C. (2006). Attention as the mediator between top management team characteristics and strategic change: The case of airline deregulation. Organization Science, 17(4), 453-469. doi: 10.1287 /orsc. 1060.0192

Cooper, D., Patel, P. C., \& Thatcher, S. M. B. (2014). It depends: 
Environmental context and the effects of faultlines on top management team performance. Organization Science, 25(2), 633-652. doi: 10.1287 /orsc. 2013.0855

Dezsö, C. L., \& Ross, D. G. (2012). Does female representation in top management improve firm performance? A panel data investigation. Strategic Management Journal, 33(9), 1072-1089. doi: $10.1002 / \mathrm{smj} .1955$

Elenkov, D. S., Judge, W., \& Wright, P. (2005). Strategic leadership and executive innovation influence: An international multi-cluster comparative study. Strategic Management Journal, 26(7), 665682. doi: $10.1002 / \mathrm{smj} .469$

Finkelstein, S., Hambrick, D., \& Cannella, A. (2009). Strategic leadership: Theory and research on executives, top management teams, and boards. New York, NY: Oxford University Press.

Friedman, Y., Carmeli, A., \& Tishler, A. (2016). How CEOs and TMTs build adaptive capacity in small entrepreneurial firms. Journal of Management Studies, 53(6), 996-1018. doi: 10.1111/joms.12184

Gong, Y. (2006). The impact of subsidiary top management team national diversity on subsidiary performance: Knowledge and legitimacy perspectives. Management International Review, 46, 771-790. doi: 10.1007/s11575-006-0126-2

Guldiken, O., Mallon, M. R., Fainshmidt, S., Judge, W. Q., \& Clark, C. E. (2019). Beyond tokenism: How strategic leaders influence more meaningful gender diversity on boards of directors. Strategic Management Journal, 4O(12), 2024-2046. doi: 10.1002/smj.3049

Hambrick, D. C. (1994). Top management groups: A conceptual integration and reconsideration of the team label. Research in Organizational Behavior, 16, 171-214.

Hambrick, D. C., Humphrey, S. E., \& Gupta, A. (2015). Research notes and commentaries structural interdependence within top management teams: A key moderator of upper echelons predictions. Strategic Management Journal, 36(3), 449-461. doi: $10.1002 / \mathrm{smj} .2230$

Hambrick, D., \& Mason, P. (1984). Upper echelons: The organization as a reflection of its top managers. Academy of Management Review, 9(2), 
193-206. doi: $10.2307 / 258434$

Harrison, D., \& Klein, K. (2007). What's the difference? Diversity constructs as separation, variety, or disparity in organizations. Academy of Management Review, 32(4), 11991228. doi: 10.5465/amr.2007.26586096

Heavey, C., \& Simsek, Z. (2015). Transactive memory systems and firm performance: An upper echelons perspective. Organization Science, 26(4), 941-959. doi: 10.1287/orsc.2015.0979

Heavey, C., \& Simsek, Z. (2017). Distributed cognition in top management teams and organizational ambidexterity: The influence of transactive memory systems. Journal of Management, 43(3), 919-945. doi: $10.1177 / 0149206314545652$

Higgins, M. C., \& Gulati, R. (2006). Stacking the deck: The effects of top management backgrounds on investor decisions. Strategic Management Journal, 27(1), 1-25. doi: 10.1002/smj.495

Hutzschenreuter, T., \& Horstkotte, J. (2013). Performance effects of top management team demographic faultlines in the process of product diversification. Strategic Management Journal, 34(6), 704726. doi: $10.1002 / \mathrm{smj} .2035$

Jackson, S. E., Joshi, A., \& Erhardt, N. L. (2003). Recent research on team and organizational diversity: SWOT analysis and implications. Journal of Management, 29(6), 801-830. doi: 10.1016/S01492063_03_00080-1

Joshi, A., \& Roh, H. (2009). The role of context in work team diversity research: A meta-analytic review. Academy of Management Journal, 52(3), 599-627. doi: 10.5465/AMJ.2009.41331491

Kaczmarek, S., \& Ruigrok, W. (2013). In at the deep end of firm internationalization: Nationality diversity on top management teams matters. Management International Review, 53(4), 513-534. doi: $10.1007 / \mathrm{s} 11575-012-0159-7$

Knight, D., Pearce, C. L., Smith, K. G., Olian, J. D., Sims, H. P., Smith, K. A., \& Flood, P. (1999). Top management team diversity, group process, and strategic consensus. Strategic Management Journal, 20(5), 445-465. doi: 10.1002/(SICI) 10970266(199905)20:5<445::AID-SMJ27>3.0.CO;2-V 
Kor, Y. Y. (2006). Direct and interaction effects of top management team and board compositions on R\&D investment strategy. Strategic Management Journal, 27(11), 1081-1099. doi: 10.1002/smj.554

Lau, D., \& Murnighan, J. (1998). Demographic diversity and faultlines: The compositional dynamics of organizational groups. Academy of Management Review, 23(2), 325-340. doi: 10.2307/259377

Lee, H., \& Park, J. (2008). The influence of top management team international exposure on international alliance formation. Journal of Management Studies, 45(5), 961-981. doi: 10.1111/j.14676486.2008.00772.x

Lin, H., \& Shih, C. (2008). How executive SHRM system links to firm performance: The perspectives of upper echelon and competitive dynamics. Journal of Management, 34(5), 853-881. doi: $10.1177 / 0149206308318612$

Ling, Y., \& Kellermanns, F. W. (2010). The effects of family firm specific sources of TMT diversity: The moderating role of information exchange frequency. Journal of Management Studies, 47(2), 322-344. doi: 10.1111/j.1467-6486.2009.00893.x

Marcel, J. J. (2009). Why top management team characteristics matter when employing a chief operating officer: A strategic contingency perspective. Strategic Management Journal, 30(6), 647-658. doi: $10.1002 / \mathrm{smj} .763$

Mihalache, O. R., Jansen, J. J. J. P., Van Den Bosch, F. A. J., \& Volberda, H. W. (2012). Offshoring and firm innovation: The moderating role of top management team attributes. Strategic Management Journal, 33(13), 1480-1498. doi: 10.1002/smj.1983

Nadolska, A., \& Barkema, H. G. (2014). Good learners: How top management teams affect the success and frequency of acquisitions. Strategic Management Journal, 35(10), 1483-1507. doi: $10.1002 / \mathrm{smj} .2172$

Narayan, S., Sidhu, J. S., \& Volberda, H. W. (2021). From attention to action: The influence of cognitive and ideological diversity in top management teams on business model innovation. Journal of Management Studies. Advance online publication. doi: $10.1111 /$ joms. 12668 
Ndofor, H. A., Sirmon, D. G., \& He, X. (2015). Utilizing the firm's resources: How TMT heterogeneity and resulting faultlines affect TMT tasks. Strategic Management Journal, 36(11), 1656-1674. doi: $10.1002 / \mathrm{smj} .2304$

Neely, B. H., Lovelace, J. B., Cowen, A. P., \& Hiller, N. J. (2020). Metacritiques of upper echelons theory: Verdicts and recommendations for future research. Journal of Management, 46(6), 1029-1062. doi: 10.1177/0149206320908640

Nielsen, B. B., \& Nielsen, S. (2013). Research notes and commentaries top management team nationality diversity and firm performance: A multilevel study. Strategic Management Journal, 34(3), 373-382. doi: $10.1002 / \mathrm{smj} .2021$

Nielsen, S. (2010a). Top management team diversity: A review of theories and methodologies. International Journal of Management Reviews, 12(3), 301-316. doi: 10.1111/j.1468-2370.2009.00263.x

Nielsen, S. (2010b). Top management team internationalization and firm performance: The mediating role of foreign market entry. Management International Review, 50(2), 185-206. doi: 10.1007/s11575-010-00290

Ou, A. Y., Seo, J. (J.), Choi, D., \& Hom, P. W. (2017). When can humble top executives retain middle managers? The moderating role of top management team faultlines. Academy of Management Journal, 6O(5), 1915-1931. doi: 10.5465/amj.2015.1072

Patel, P. C., \& Cooper, D. (2014). Structural power equality between family and non-family TMT members and the performance of family firms. Academy of Management Journal, 57(6), 1624-1649. doi: 10.5465/amj.2012.0681

Qian, C., Cao, Q., \& Takeuchi, R. (2012). Research notes and commentaries top management team functional diversity and organizational innovation in China: The moderating effects of environment. Strategic Management Journal, 34(1), 110-120. doi: $10.1002 / \mathrm{smj} .1993$

Richard, O. C., Wu, J., Markoczy, L. A., \& Chung, Y. (2019). Top management team demographic-faultline strength and strategic change: What role does environmental dynamism play? 
Strategic Management Journal, 4O(1), 987-1009. doi: 10.1002/smj.3009

Schubert, T., \& Tavassoli, S. (2020). Product innovation and educational diversity in top and middle management teams. Academy of Management Journal, 63(1), 272-294. doi: 10.5465/amj.2017.0741

Siegel, P. A., \& Hambrick, D. C. (2005). Pay disparities within top management groups: Evidence of harmful effects on performance of high-technology firms. Organization Science, 16(3), 259-274. doi: 10.1287 /orsc. 1050.0128

Singh, D. A., Gaur, A. S., \& Schmid, F. P. (2010). Corporate diversification, TMT experience, and performance: Evidence from German SMEs. Management International Review, 50(1), 35-56. doi: 10.1007/s11575-009-0025-4

Smith, K. G., Collins, C. J., \& Clark, K. D. (2005). Existing knowledge, knowledge creation capability, and the rate of new product introduction in high-technology firms. Academy of Management Journal, 48(2), 346-357. doi: 10.5465/AMJ.2005.16928421

Smith, K., Smith, K., Olian, J., Sims, H., O’Bannon, D., \& Scully, J. (1994). Top management team demography and process: The role of social integration and communication. Administrative Science Quarterly, 39(3), 412-438. doi: 10.2307/2393297

Souitaris, V., \& Maestro, B. M. M. (2010). Polychronicity in top management teams: The impact on strategic decision processes and performance of new technology ventures. Strategic Management Journal, 31(6), 652-678. doi: 10.1002/smj.831

Steinbach, A. L., Holcomb, T. R., Holmes, R. M., Devers, C. E., \& Cannella, A. A. (2017). Top management team incentive heterogeneity, strategic investment behavior, and performance: A contingency theory of incentive alignment. Strategic Management Journal, 38(8), 17011720. doi: $10.1002 / \mathrm{smj} .2628$

Takahashi, N. (2014). Future parameter explains job satisfaction and turnover candidates in Japanese companies. Annals of Business Administrative Science, 13, 129-140. doi: 10.7880/abas.13.129

Takahashi, N. (2015). Japanese work ethic and culture: A new paradigm of intrinsic motivation. Annals of Business Administrative Science, 14, 
261-278. doi: 10.7880/abas. 14.261

Takahashi, N., Ohkawa, H., \& Inamizu, N. (2014). Spurious correlation between self-determination and job satisfaction: A case of Company $\mathrm{X}$ from 2004-2013. Annals of Business Administrative Science, 13, 243254. doi: $10.7880 /$ abas. 13.243

Triana, M. d. C., Miller, T. L., \& Trzebiatowski, T. M. (2014). The doubleedged nature of board gender diversity: Diversity, firm performance, and the power of women directors as predictors of strategic change. Organization Science, 25(2), 609-632. doi: 10.1287 /orsc. 2013.0842

Wei, L., \& Wu, L. (2013). What a diverse top management team means: Testing an integrated model. Journal of Management Studies, 5O(3), 389-412. doi: 10.1111/joms. 12013

Yamauchi, N., \& Sato, H. (2021, August). Diverse more than ever. Paper presented at ABAS Conference 2021 Summer, University of Tokyo, Japan.

Yoo, J. W., Reed, R., Shin, S. J., \& Lemak, D. J. (2009). Strategic choice and performance in late movers: Influence of the top management team's external ties. Journal of Management Studies, 46(2), 308335. doi: 10.1111/j.1467-6486.2008.00802.x

Zhang, X., Li, N., Ullrich, J., \& van Dick, R. (2015). Getting everyone on board: The effect of differentiated transformational leadership by CEOs on top management team effectiveness and leader-rated firm performance. Journal of Management, 41(7), 1898-1933. doi: $10.1177 / 0149206312471387$ 